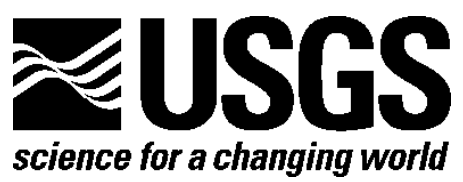

\title{
Internet-based Modeling, Mapping, and Analysis for the Greater Everglades (IMMAGE; Version 1.0): Web-based Tools to Assess the Impact of Sea Level Rise in South Florida
}

By Paul Hearn, David Strong, Eric Swain, and Jeremy Decker

Open-File Report 2013-1185

U.S. Department of the Interior

U.S. Geological Survey 


\section{U.S. Department of the Interior \\ SALLY JEWELL, Secretary}

\section{U.S. Geological Survey \\ Suzette M. Kimball, Acting Director}

U.S. Geological Survey, Reston, Virginia: 2013

For more information on the USGS—the Federal source for science about the Earth,

its natural and living resources, natural hazards, and the environment-visit

http://www.usgs.gov or call 1-888-ASK-USGS

For an overview of USGS information products, including maps, imagery, and publications, visit $h$ ttp://www.usgs.gov/pubprod

To order this and other USGS information products, visit $h$ ttp://store.usgs.gov

Suggested citation:

Hearn, Paul, Strong, David, Swain, Eric, and Decker, Jeremy, 2013, Internet-based Modeling, Mapping, and Analysis for the Greater Everglades (IMMAGE; Version 1.0)—Web-based tools to assess the impact of sea level rise in south Florida: U.S. Geological Survey Open-File Report 2013-1185, 17 p., ht tp://pubs.usgs.gov/of/2013/1185.

Any use of trade, firm, or product names is for descriptive purposes only and does not imply endorsement by the U.S. Government.

Although this information product, for the most part, is in the public domain, it also may contain copyrighted materials as noted in the text. Permission to reproduce copyrighted items must be secured from the copyright owner. 


\section{Contents}

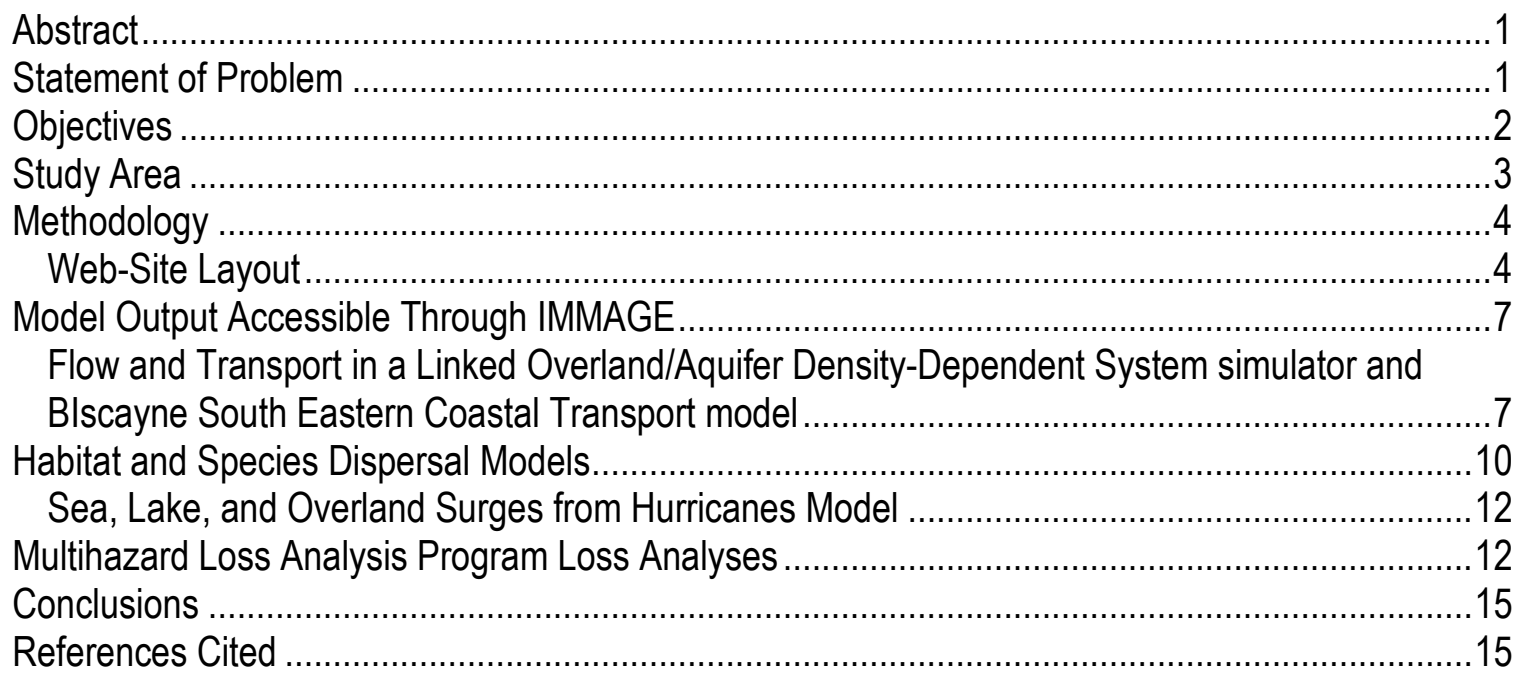

\section{Figures}

1. Generalized schematic of the U.S. Geological Survey's Internet-based Modeling, Mapping, and Analysis for the Greater Everglades Web-based model interface.

2. Internet-based Modeling, Mapping, and Analysis for the Greater Everglades study area and coverage of the Blscayne SouthEastern Coastal Transport; Habitat Suitability; Sea, Lake, and Overland Surges from Hurricanes; and the Federal Emergency Management Agency's multihazard loss analysis program models.

3. The U.S. Geological Survey's Internet-based Modeling, Mapping, and Analysis for the Greater Everglades Web-site entry page.....

4. The U.S. Geological Survey's Internet-based Modeling, Mapping, and Analysis for the Greater Everglades saltwater intrusion applet.

5. The U.S. Geological Survey's Internet-based Modeling, Mapping, and Analysis for the Greater Everglades full GIS Web interface provides more advanced users with a suite of tools to display model output on maps or imagery, or in tabular or graphical format........6

6. This screenshot of the U.S. Geological Survey's Internet-based Modeling, Mapping, and Analysis for the Greater Everglades full GIS Web interface shows a BIscayne South Eastern Coastal Transport model analysis of the impact of a $60-\mathrm{cm}$ sea level rise on the areal extent of saltwater intrusion in the area around central Miami, Florida....10

7. Screenshot of the U.S. Geological Survey's Internet-based Modeling, Mapping, and Analysis for the Greater Everglades Habitat Suitability applet showing forecasted amphibian species richness for a sea level rise of $30 \mathrm{~cm}$

8. Screenshot of the U.S. Geological Survey's Internet-based Modeling, Mapping, and Analysis for the Greater Everglades Sea, Lake, and Overland Surges from Hurricanes (SLOSH) storm surge applet, showing the spatial extent and depth of surge forecasted in the Miami area for a Category 5 hurricane 
9. Screenshot of the U.S. Geological Survey's Internet-based Modeling, Mapping, and Analysis for the Greater Everglades multihazard loss analysis program Surge Loss applet, showing the distribution of forecasted losses from daytime damages to vehicles in the greater Miami area for a Category 5 hurricane .......................................................

\section{Table}

1. Input parameters for the Blscayne SouthEastern Coastal Transport (BISECT)..................8 


\section{Conversion Factors}

Inch/Pound to SI

\begin{tabular}{|c|c|c|}
\hline Multiply & By & To obtain \\
\hline \multicolumn{3}{|c|}{ Length } \\
\hline inch (in.) & 2.54 & centimeter $(\mathrm{cm})$ \\
\hline foot $(\mathrm{ft})$ & 0.3048 & meter (m) \\
\hline mile (mi) & 1.609 & kilometer (km) \\
\hline yard (yd) & 0.9144 & meter $(\mathrm{m})$ \\
\hline
\end{tabular}

SI to Inch/Pound

\begin{tabular}{llll}
\hline \multicolumn{1}{c}{ Multiply } & By & To obtain \\
\hline centimeter $(\mathrm{cm})$ & Length & \\
meter $(\mathrm{m})$ & 0.3937 & inch (in.) & \\
kilometer $(\mathrm{km})$ & 3.281 & foot (ft) & \\
meter $(\mathrm{m})$ & 0.6214 & mile (mi) & \\
\hline
\end{tabular}




\title{
Internet-based Modeling, Mapping, and Analysis for the Greater Everglades (IMMAGE; Version 1.0): Web-based Tools to Assess the Impact of Sea Level Rise in South Florida
}

\author{
By Paul Hearn, David Strong, Eric Swain, and Jeremy Decker
}

\begin{abstract}
South Florida's Greater Everglades area is particularly vulnerable to sea level rise, due to its rich endowment of animal and plant species and its heavily populated urban areas along the coast. Rising sea levels are expected to have substantial impacts on inland flooding, the depth and extent of surge from coastal storms, the degradation of water supplies by saltwater intrusion, and the integrity of plant and animal habitats. Planners and managers responsible for mitigating these impacts require advanced tools to help them more effectively identify areas at risk. The U.S. Geological Survey's (USGS) Internet-based Modeling, Mapping, and Analysis for the Greater Everglades (IMMAGE) Web site has been developed to address these needs by providing more convenient access to projections from models that forecast the effects of sea level rise on surface water and groundwater, the extent of surge and resulting economic losses from coastal storms, and the distribution of habitats. IMMAGE not only provides an advanced geographic information system (GIS) interface to support decision making, but also includes topicbased modules that explain and illustrate key concepts for nontechnical users. The purpose of this report is to familiarize both technical and nontechnical users with the IMMAGE Web site and its various applications.
\end{abstract}

\section{Statement of Problem}

Recent analyses using current Intergovernmental Panel on Climate Change (IPCC) projections of sea level rise and Light Detection and Ranging (lidar) data for the eastern portions of Miami-Dade County suggest that coastal areas in South Florida will be subjected to the degradation of coastal habitats, contamination of municipal water supplies by the intrusion of saltwater into coastal aquifers, alteration of groundwater flow patterns, and increased risk of surge-related flooding and wind damage from coastal storms (Doyle and others, 2007; Renken, 2005). It is critical that water planners, as well as park managers and municipal authorities, have the best tools available to assess the societal risks and economic impacts that these adverse environmental changes could have on nearby communities, protected lands, and the region as a whole.

Furthermore, development and water management policies being debated today in South Florida will commit public and private capital to infrastructure and facilities with 
design lives (the periods of time during which infrastructure and facilities are expected by their designers to operate within their specified parameters) extending well into the period of time when the impacts of sea level rise are expected to occur. Surface-water control canals, municipal water distribution networks, and wastewater and storm water collection systems have design lives on the order of 30 to 75 years. Sewage treatment and wastewater reclamation facilities have design lives close to 50 years. The anticipated rise in sea level during the next century may compromise the functioning of these engineered systems and may stress the ability of associated natural systems to adapt.

Recently, numerical models have been developed to forecast the impact of sea level rise on saltwater intrusion, inland flooding, surge from coastal storms, and the resulting impact on the suitability of habitat for key species in the Greater Everglades. These models are among our most powerful tools in forecasting future trends and evaluating alternative restoration and preservation policies. Unfortunately, the full potential of these models is often not realized. If an analyst wants to evaluate how changing the input parameters of a model affects the results, the model will typically need to be run again using the new parameters. Since many models take hours or even days to run, evaluating a large number of parameter sets can be a time-consuming and tedious process. Furthermore, due to their inherent complexity, it is usually not practical to make them available to the general public.

\section{Objectives}

IMMAGE's principal objective is to develop a coupled GIS-enabled Web-based framework to provide interactive model-based scenarios to evaluate the potential impact of sea level rise on water supply, inland flooding, storm surge, and habitat management in South Florida. The framework will allow scientists, local planners, and resource managers to evaluate the impact of sea level rise on:

1. saltwater intrusion into coastal water well fields,

2. the optimal use of canals to impede the inland movement of saline groundwater,

3. urban flooding,

4. the risk to populated areas and natural habitat from catastrophic storm surge,

5. wetland inundation periods and depths, and

6. habitat distribution.

The IMMAGE Web site provides a framework of online GIS-based interfaces to four selected models, thereby enhancing their usability and making them available to a broad user community. The approach is relatively simple: by running models in advance, using the maximum likely range of input parameters, all the necessary model output can be stored in a server database (fig. 1). Web applications can then be developed to allow users to select the desired input parameters, retrieve the necessary model output from the database, and display the output in a map viewer with other relevant data — all online. Without the need to actually run the models online, this process is relatively fast, allowing the user to evaluate multiple scenarios in a short period of time. 


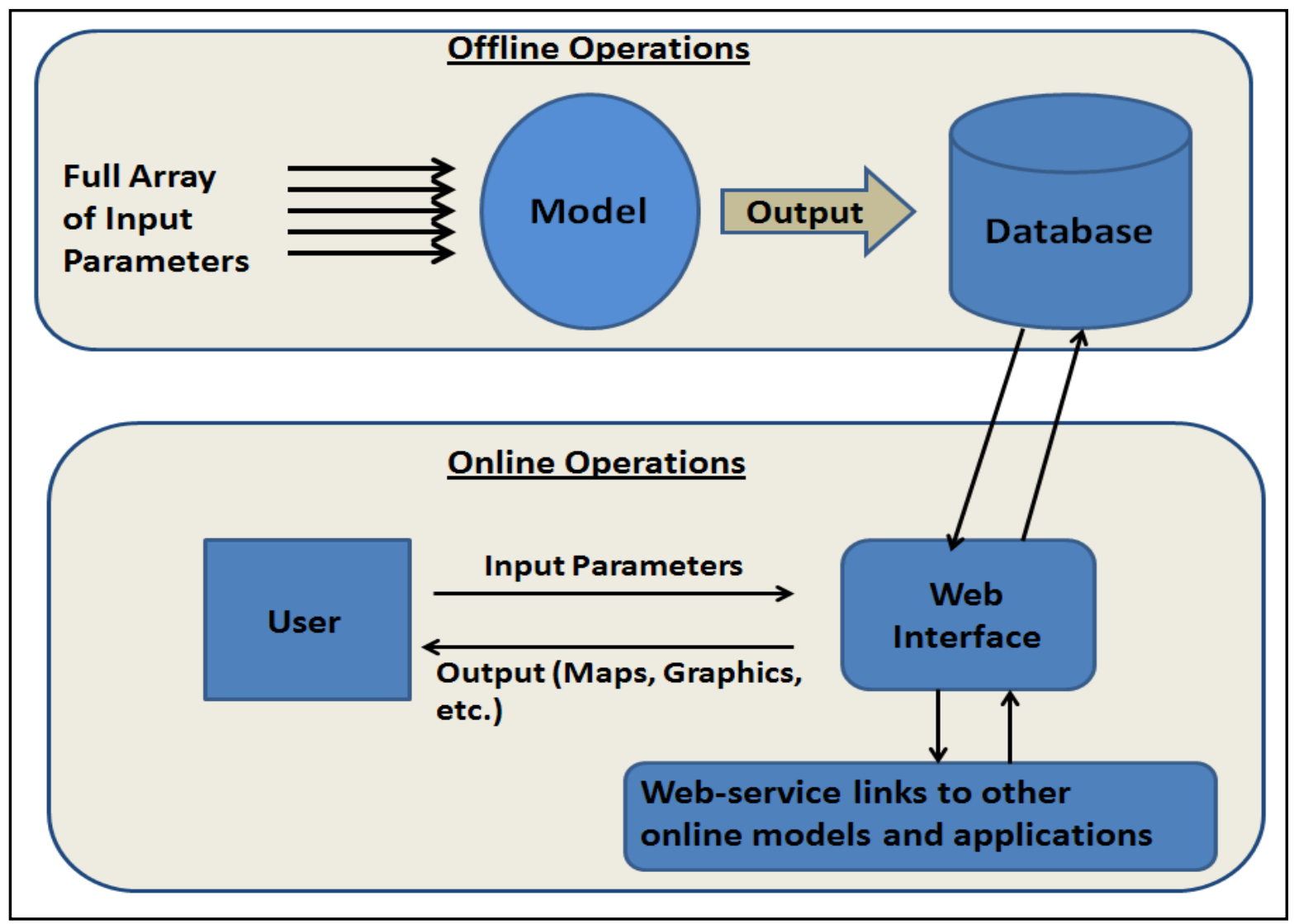

Figure 1. Generalized schematic of the U.S. Geological Survey's Internet-based Modeling, Mapping, and Analysis for the Greater Everglades (IMMAGE) Web-based model interface.

IMMAGE's Web interface provides access to the following four models:

1. The BIscayne SouthEastern Coastal Transport (BISECT) model, a coupled groundwater and surface-water model developed by the U.S. Geological Survey (USGS) (Lohmann and others, 2010).

2. Habitat distribution models, which utilize output from BISECT, developed at the Everglades National Park (Pearlstine and others, 2006).

3. Sea, Lake, and Overland Surges from Hurricanes (SLOSH) model developed by the National Oceanic and Atmospheric Administration's (NOAA) National Hurricane Center (NOAA/NHC) (http://www.nhc.noaa.gov/ssurge/ssurge_slosh.shtml), and

4. The Federal Emergency Management Agency's (FEMA) multihazard loss analysis program [HAZUS-MH (HAZUS)] (http://www.fema.gov/hazus).

\section{Study Area}

The area covered by this project includes the Everglades National Park and Biscayne National Park (ENP and BNP), Miami-Dade and Monroe Counties, and the eastern portions of Broward and Palm Beach Counties. Output from the BISECT and habitat suitability models is available for the ENP and BNP, and coastal areas of Monroe 
and Miami Dade County. SLOSH and HAZUS model output is available for MiamiDade, Broward, and Palm Beach Counties (fig. 2).

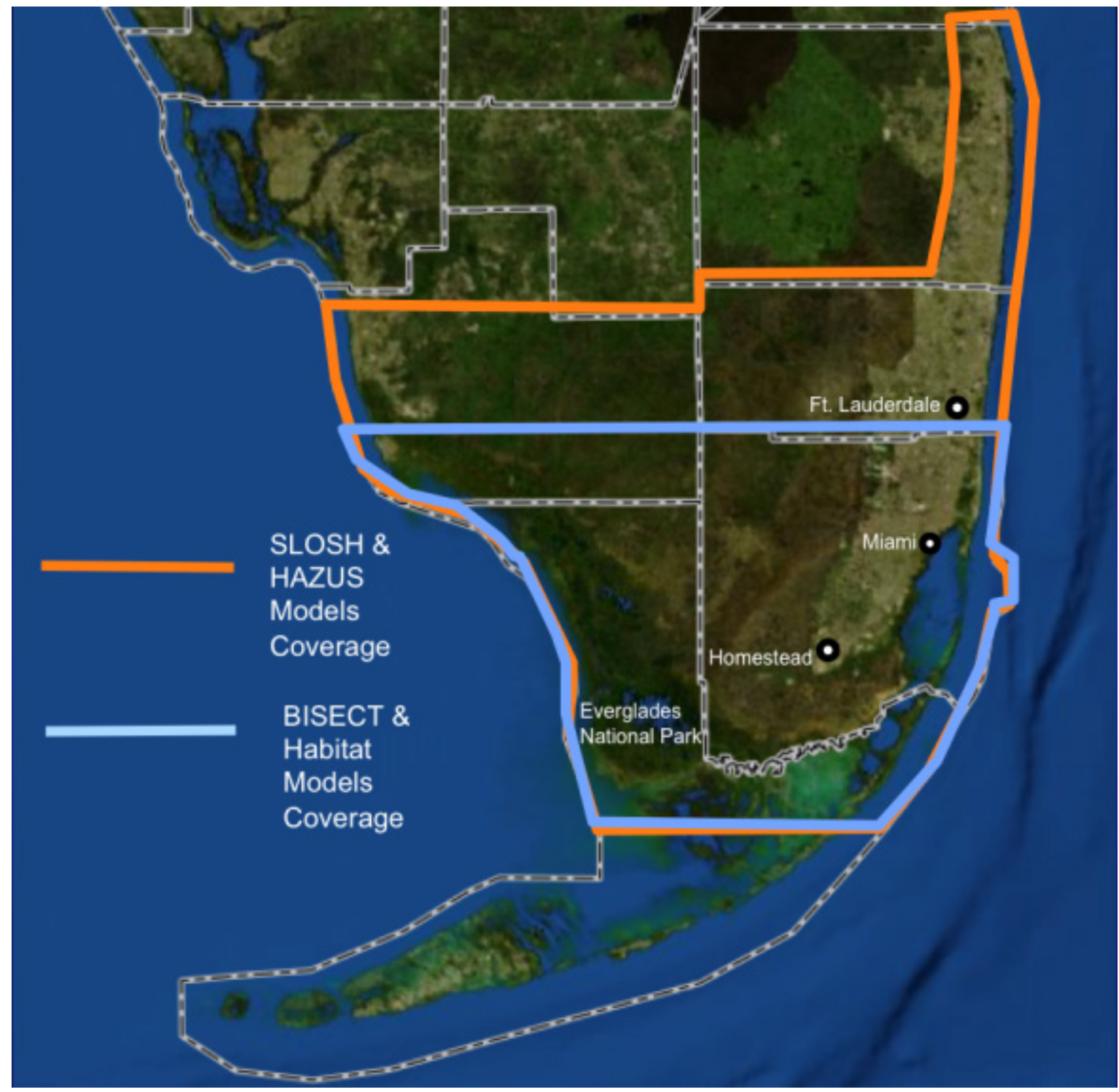

Figure 2. Internet-based Modeling, Mapping, and Analysis for the Greater Everglades (IMMAGE) study area and coverage of the Blscayne SouthEastern Coastal Transport (BISECT); Habitat Suitability; Sea, Lake, and Overland Surges from Hurricanes (SLOSH); and the Federal Emergency Management Agency's (FEMA) multihazard loss analysis program (HAZUS) models. The dashed black-and-white lines delineate county boundaries.

\section{Methodology}

\section{Web-Site Layout}

To accommodate interest on the part of the public without a technical background in the subject matter, including Federal, State, and local officials, academia, journalists, and the general public, IMMAGE provides several examples of how model output can be 
applied (fig. 3). Each example includes a brief overview of the specific issue and a GISbased application (applet) demonstrating how the relevant model can be utilized to support decision making (fig. 4). For more advanced users, IMMAGE's complete GIS Web interface provides access to output from all four of the models, as well as various tools to view and display data (fig. 5).

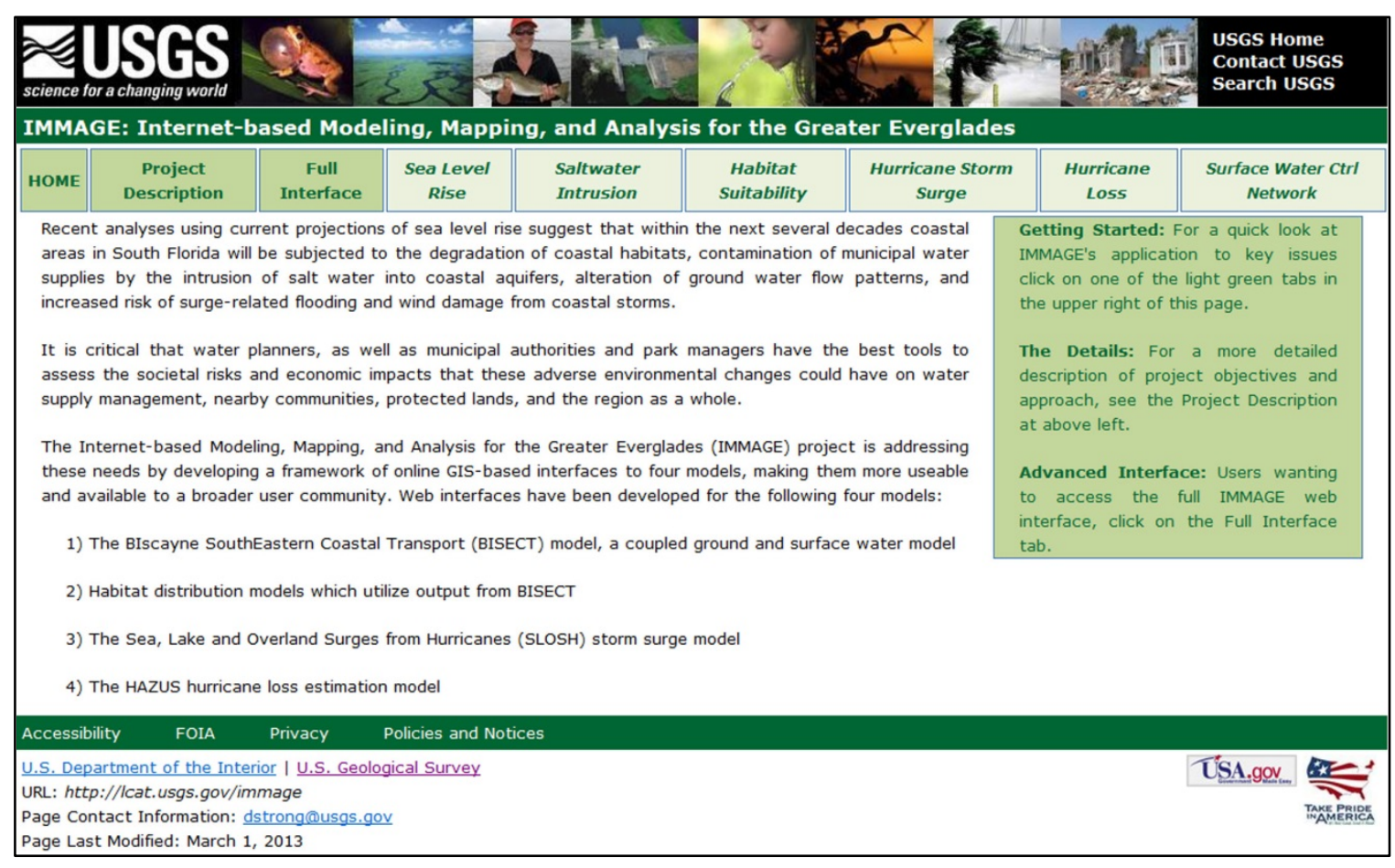

Figure 3. The U.S. Geological Survey's Internet-based Modeling, Mapping, and Analysis for the Greater Everglades (IMMAGE) Web-site entry page. Tabs at the top of the page link to applets demonstrating how model output can be applied to decisionmaking related to specific issues. 


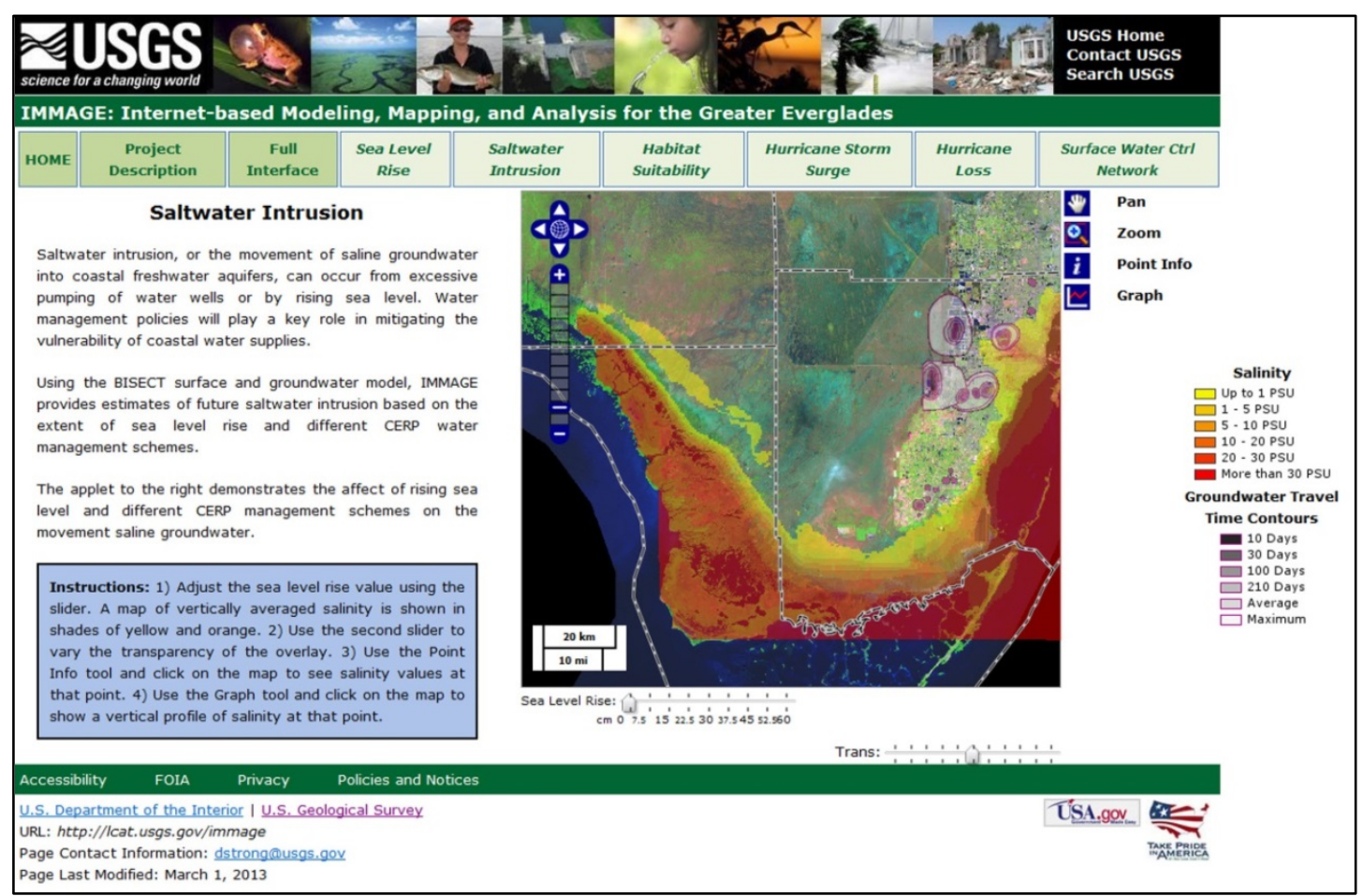

Figure 4. The U.S. Geological Survey's Internet-based Modeling, Mapping, and Analysis for the Greater Everglades (IMMAGE) saltwater intrusion applet.

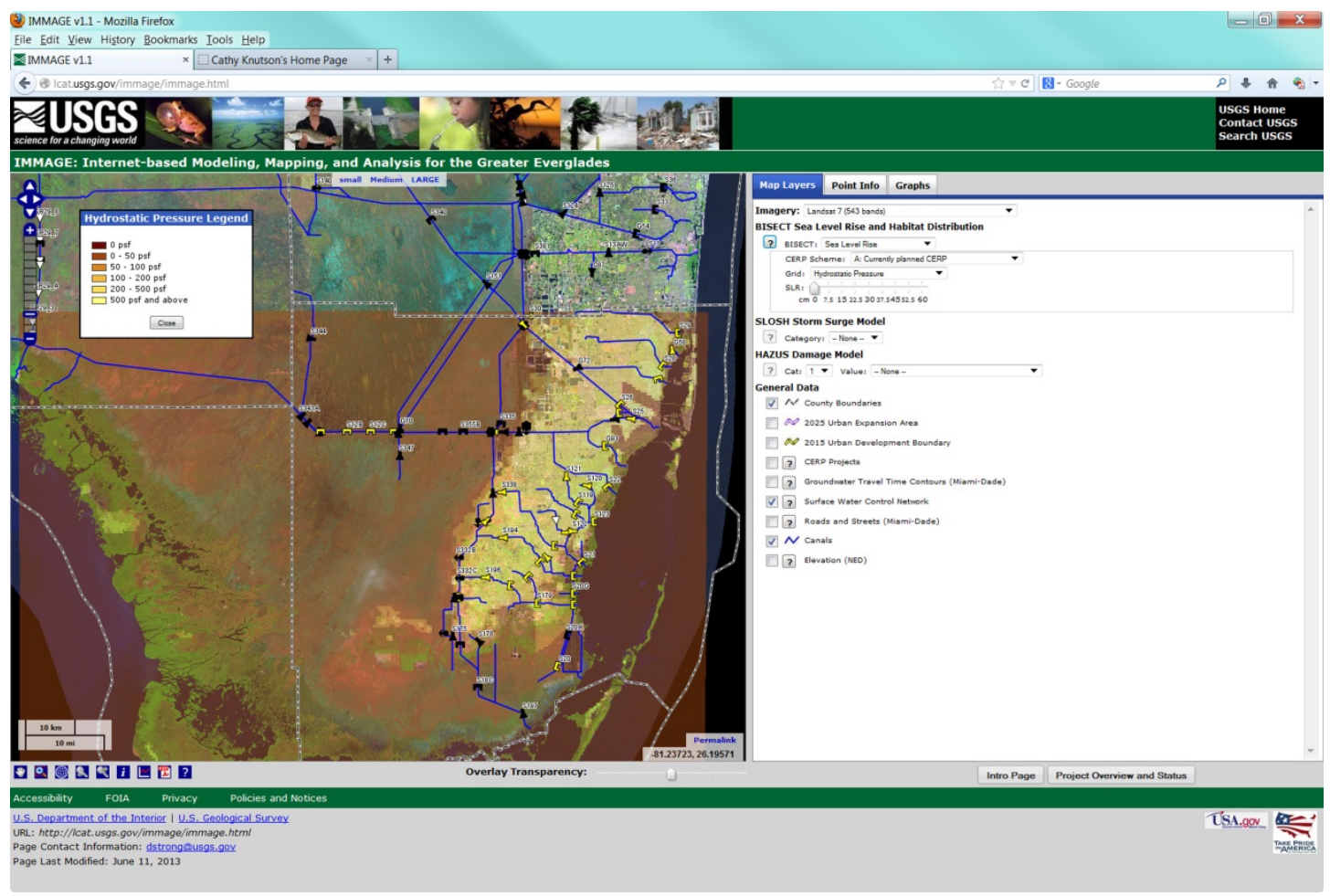

Figure 5. The U.S. Geological Survey's Internet-based Modeling, Mapping, and Analysis for the Greater Everglades (IMMAGE) full GIS Web interface provides more advanced users with a suite of tools to display model output on maps or imagery, or in tabular or graphical format. 


\section{Model Output Accessible Through IMMAGE}

\section{Flow and Transport in a Linked Overland/Aquifer Density-Dependent System simulator and Blscayne South Eastern Coastal Transport model}

The Flow and Transport in a Linked Overland/Aquifer Density-Dependent System (FTLOADDS) simulator has been developed over a number of years. It began with a surface-water application to the coastal area along Florida Bay using the Simulation of Surface-Water Integrated Flow and Transport in Two Dimensions model (SWIFT2D) (Schaffranek, 2004; Swain and others, 2004; Swain, 2005). Groundwater flow was incorporated into this simulation by coupling SWIFT2D with SEAWAT, a generic simulator of groundwater flow and transport (Langevin and others, 2005). This coupled scheme is called FTLOADDS. The model area was expanded to encompass the whole Everglades National Park (ENP) area and referred to as the Tides and Inflows in the Mangrove Everglades (TIME) model (Wang and others, 2007). This model has been used to represent hydrologic restoration scenarios for the Comprehensive Everglades Restoration Plan (CERP).

The FTLOADDS simulator was additionally applied to the Ten Thousand Islands area (Swain and Decker, 2009) and to the Biscayne Bay coast (Wolfert-Lohmann and others, 2008; Swain and others, 2009). The Biscayne Bay model was then combined with the TIME model to produce the BIscayne South Eastern Coastal Transport (BISECT) model. The BISECT model incorporates some of the most important natural and urban areas in South Florida and is useful in examining the effects of hydrologic factors. Applications include evaluation of the impact of sea level rise (SLR) on future forecasts with varying levels of sea level rise in conjunction with CERP restoration changes and hindcast simulation to represent historical and transient conditions.

Experiments on various SLR scenarios have been performed with BISECT, which uses the FTLOADDS simulator for flow and transport in a coupled hydrodynamic surface-water/groundwater system. The existing conditions simulation runs for the 7-year period January 1, 1996 through December 31, 2002 . BISECT is a combination of two model domains that were developed separately; the TIME domain west of the L-31N Canal (Wang and others, 2007) and the Biscayne domain from the L-31N Canal to offshore Biscayne Bay (Swain and others, 2009). This combination allows the examination of the entire coastal region from the Barron River in the western side of the study area to the C-9 Canal outlet just north of Fort Lauderdale. The input parameters used in the BISECT runs, plus temporal and spatial resolutions, are provided in table 1. 
Table 1. Input parameters for the Blscayne SouthEastern Coastal Transport (BISECT).

[ft, feet; h, hours; $\mathrm{m}$, meters; min, minutes]

\begin{tabular}{|c|c|c|c|}
\hline Input parameter & $\begin{array}{c}\text { Temporal } \\
\text { resolution }\end{array}$ & Spatial resolution & Source \\
\hline Topography/bathymetry & Static & $\begin{array}{l}500 \mathrm{~m} \\
{[1,640 \text { feet }(\mathrm{ft})] .}\end{array}$ & $\begin{array}{l}\text { Airborne helicopter and } \\
\text { digital elevation models. }\end{array}$ \\
\hline $\begin{array}{l}\text { Aquifer dimensions and } \\
\text { conductivity. }\end{array}$ & Static & $\begin{array}{l}500 \mathrm{~m} \\
(1,640 \mathrm{ft}) \\
\text { horizontal and } \\
2 \mathrm{~m}(6.6 \mathrm{ft}) \\
\text { vertical. }\end{array}$ & $\begin{array}{l}\text { Field studies and } \\
\text { documentation. }\end{array}$ \\
\hline $\begin{array}{l}\text { Surface-water frictional } \\
\text { resistance. }\end{array}$ & Static & $500 \mathrm{~m}$ & $\begin{array}{l}\text { Field studies and } \\
\text { calibration. }\end{array}$ \\
\hline $\begin{array}{l}\text { Groundwater/surface- } \\
\text { water leakage } \\
\text { coefficients. }\end{array}$ & Static & $\begin{array}{l}500 \mathrm{~m} \\
(1,640 \mathrm{ft}) .\end{array}$ & $\begin{array}{l}\text { Aquifer properties and } \\
\text { calibration. }\end{array}$ \\
\hline Groundwater boundaries & Daily & $\begin{array}{l}500 \mathrm{~m} \\
(1,640 \mathrm{ft})\end{array}$ & Field well levels. \\
\hline Surface-water inflows & Daily & $\begin{array}{l}500 \mathrm{~m} \\
(1,640 \mathrm{ft})\end{array}$ & $\begin{array}{l}\text { Hydraulic structure } \\
\text { flow measurements. }\end{array}$ \\
\hline Tidal boundaries & $30 \mathrm{~min}$ & Variable & $\begin{array}{l}\text { Tidal components } \\
\text { derived from Fourier } \\
\text { analysis of offshore } \\
\text { stations. }\end{array}$ \\
\hline Precipitation & $6 \mathrm{~h}$ & $\begin{array}{l}\text { Eight zones } \\
\text { covering entire } \\
\text { area. }\end{array}$ & $\begin{array}{l}\text { Interpolated rain-gage } \\
\text { measurements. }\end{array}$ \\
\hline $\begin{array}{l}\text { Solar radiation } \\
\text { (evapotranspiration). }\end{array}$ & $30 \mathrm{~min}$ & $\begin{array}{l}\text { One value for } \\
\text { area. }\end{array}$ & Pyranometer. \\
\hline $\begin{array}{l}\text { Air temperature and } \\
\text { humidity } \\
\text { (evapotranspiration). }\end{array}$ & $30 \mathrm{~min}$ & $\begin{array}{l}\text { One value for } \\
\text { area. }\end{array}$ & Weather station. \\
\hline $\begin{array}{l}\text { Albedo } \\
\text { (evapotranspiration). }\end{array}$ & Static & $\begin{array}{l}500 \mathrm{~m} \\
(1,640 \mathrm{ft})\end{array}$ & $\begin{array}{l}\text { Based on depth below } \\
\text { sea level from } \\
\text { experimentation. }\end{array}$ \\
\hline Canal levels & Daily & Variable & $\begin{array}{l}\text { Hydraulic structure } \\
\text { stage measurements. }\end{array}$ \\
\hline Wind & $30 \mathrm{~min}$ & $\begin{array}{l}\text { One value for } \\
\text { area. }\end{array}$ & Weather station. \\
\hline Groundwater pumpage & Daily & $\begin{array}{l}\text { For each major } \\
\text { well field. }\end{array}$ & Municipal well records. \\
\hline
\end{tabular}


IMMAGE allows users to display BISECT output on imagery or map backgrounds, or as vertical profiles in tabular or graphical form. BISECT output includes the following parameters:

1. Inland flooding (as maximum depth, percent inundation or percent continuous inundation),

2. Groundwater salinity,

3. Groundwater conductivity,

4. Depth to water table, and

5. Hydrostatic pressure.

Model input parameters include future sea level $(0$ to $60 \mathrm{~cm} ; 0$ to $2 \mathrm{ft}$ ) and CERP scenarios (CERP A, currently planned; CERP B, more rapid progress; and CERP C, no change from current conditions).

Figure 6 shows a screenshot of BISECT model projections of groundwater salinities for an SLR of $60 \mathrm{~cm}(2 \mathrm{ft})$. Purpose contour lines around municipal water-well fields depict groundwater travel times from various points; blue lines and black icons represent canals and surface-water control structures, respectively. Forecasted groundwater salinities, depicted in the map view as the vertical average of salinities within the Biscayne aquifer, indicate a clear threat to the two easternmost well fields. On the right side of figure 6 , a more precise impact assessment is shown by the vertical profiles plotted by IMMAGE for the point indicated by the red cross highlighted in the middle of the map. These profiles reflect BISECT forecasts of salinity profiles for CERP Plans A, B, and C (designated as Schemes A, B, and C in figure 6). BISECT forecasts the CERP C (no action) scenario to result in dramatically increased groundwater salinities, reflecting the absence of freshwater routed through canals to impede the inland migration of saline groundwater. While BISECT predicts substantially lower salinities for CERP A and B scenarios, the impact may still be sufficient to require mitigation. 


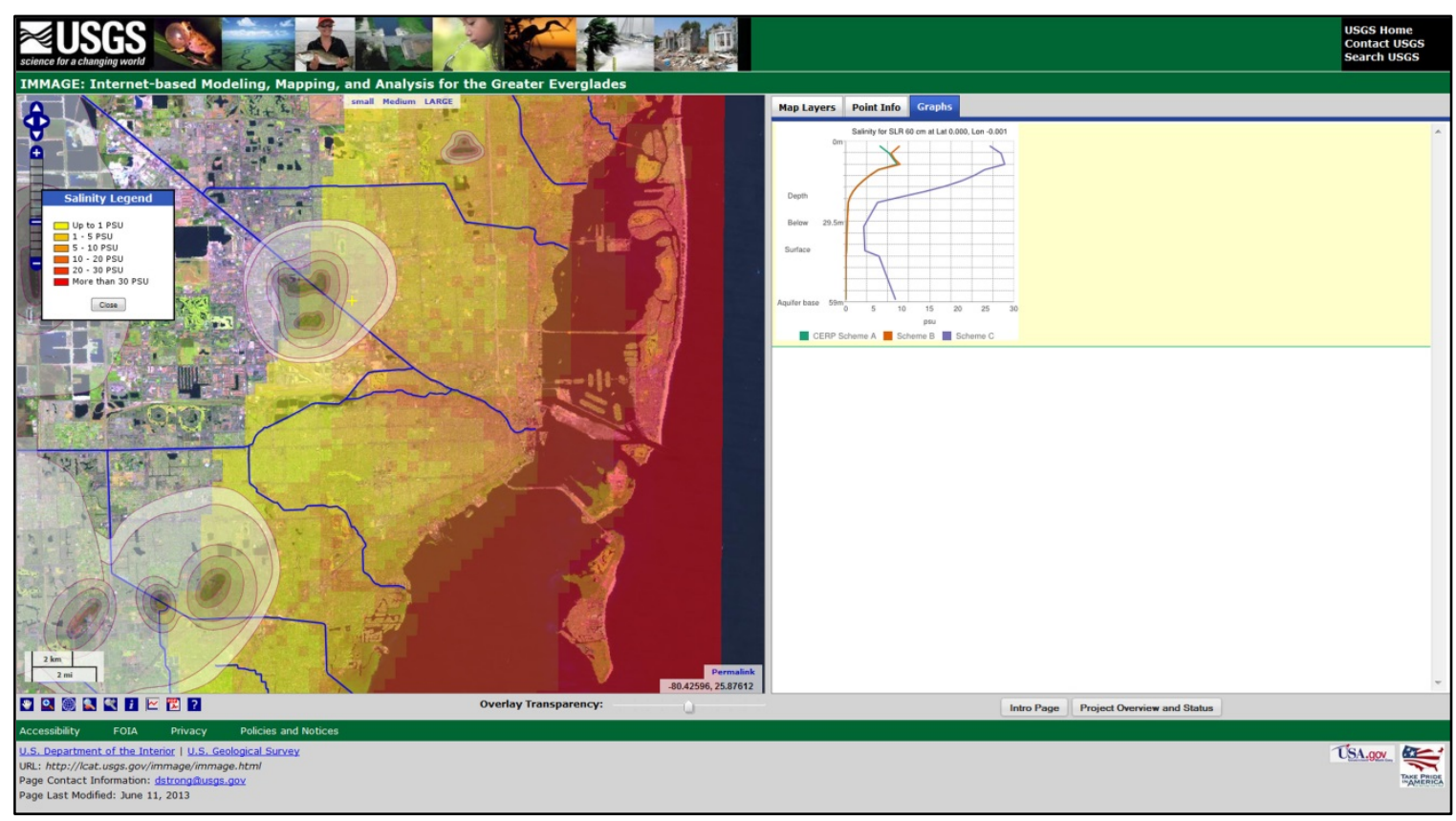

Figure 6. This screenshot of the U.S. Geological Survey's Internet-based Modeling, Mapping, and Analysis for the Greater Everglades (IMMAGE) full GIS Web interface shows a Blscayne South Eastern Coastal Transport (BISECT) model analysis of the impact of a 60-cm (2-ft) sea level rise on the areal extent of saltwater intrusion in the area around central Miami, Florida.

\section{Habitat and Species Dispersal Models}

The Everglades are endowed with habitats for several unique species of plants and animals, many of which are rare or endangered. Due to its extremely low relief, this area is quite vulnerable to the effects of SLR. Relatively small increases in sea level are expected to lead to large increases in inundation periods for broad areas in the park, and have already influenced both surface and subsurface saltwater intrusion (Stabenau and others, 2011). The inland migration of saline surface and groundwater has most likely increased due to lower freshwater discharge associated with upstream development over the past century. These hydrologic changes put pressure on the ecosystem, causing a variety of impacts, such as inland migration of plants, variation in species composition, and disruptions of predator-prey relationships (Pearlstine and others, 2010). Mangrove species resistant to higher salinities have already migrated approximately $3 \mathrm{~km}(2 \mathrm{mi})$ inland since the 1940s in parts of the national park, presumably in response to rising sea level (Ross and others, 2000). The coastal habitats of Everglades National Park are at the end of the hydrologic restoration chain, but are the first areas to be impacted by SLR. Consequently, both restoration and SLR may cause substantial spatial changes in habitat availability and distribution.

The ability of species to migrate among core habitat areas is impacted by changes in South Florida habitat connectivity resulting from urban growth, sea level rise, and restoration-stimulated habitat succession. The USGS, in cooperation with the South Florida Natural Resources Center, Everglades National Park (SFNRC/ENP) (Labiosa and others, 2009), is developing and testing metrics for ranking the potential for wildlife species dispersal under alternative changes to the natural landscape and urban growth. 
The Circuitscape model (McRae and others, 2008) provides the mechanism for evaluation of species dispersal. Circuitscape algorithms adapt electronic circuit theory to predict patterns of movement, gene flow, and genetic differentiation among plant and animal populations in heterogeneous landscapes.

Coastal models for juvenile spotted seatrout (Cynoscion nebulosus), blue crab (Callinectes sapidus), and turtle grass (Thalassia testudinum) have been developed at the SFNRC/ENP (fig. 7). The models are coupled to the BISECT hydrologic model to simulate changes in habitat suitability under scenarios of restoration and SLR (Pearlstine and others, 2008, 2010). The graphical user interface provided by IMMAGE is not only an effective and practical way for scientists and managers to view data without the need for their own GIS software; it also provides a convenient tool to educate the nontechnical public on the issue of habitat vulnerability. The spotted seatrout, blue crab, and turtle grass models were originally developed for the Caloosahatchee estuary and applied to Florida Bay. These models are not a perfect fit, but were available and serve to demonstrate the utility of IMMAGE in addressing habitat change. For application to South Florida, these models should be considered early implementations because validation studies have not been conducted yet. IMMAGE provides a modular approach that will be of value to newer habitat models as they become available.

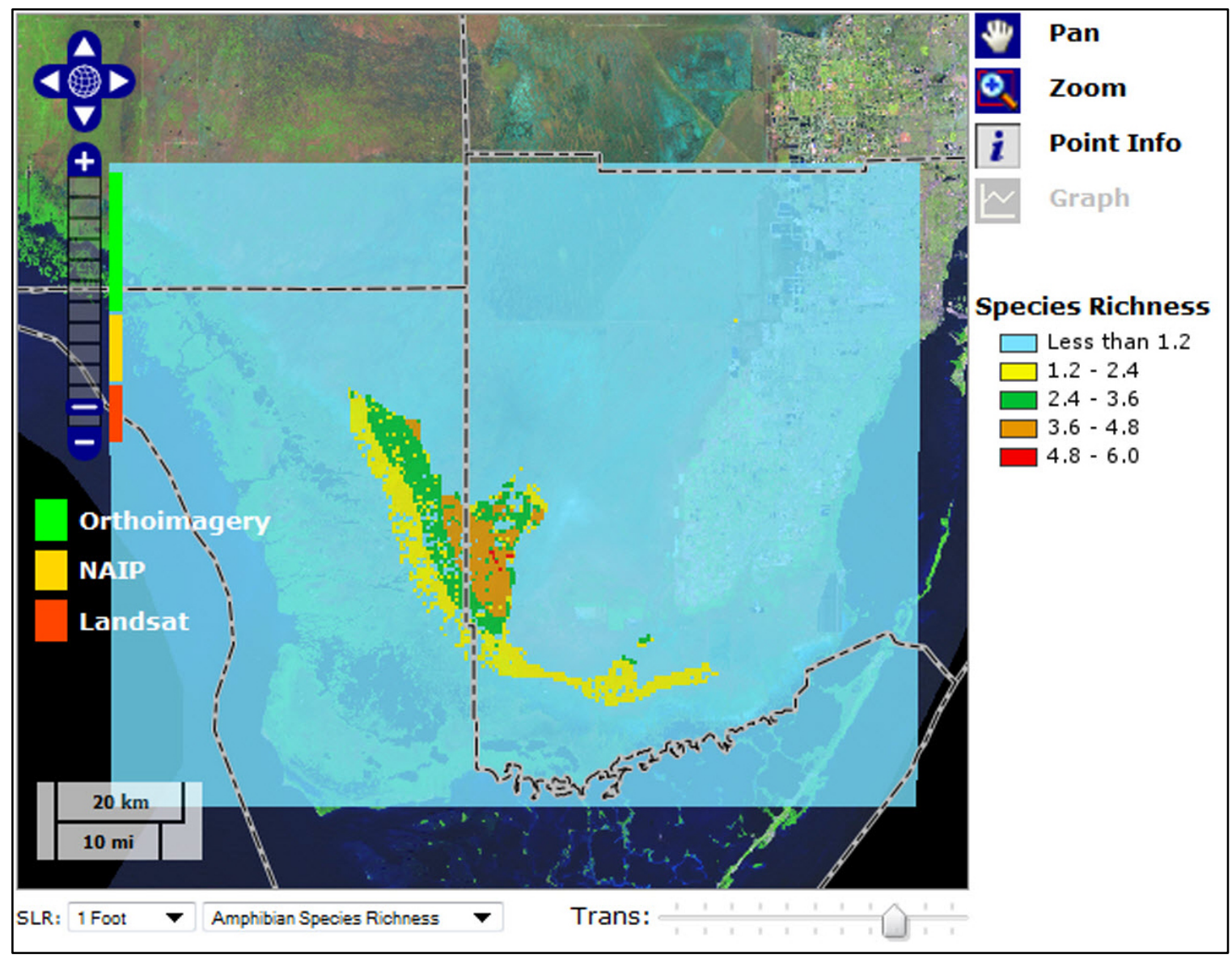

Figure 7. Screenshot of the U.S. Geological Survey's Internet-based Modeling, Mapping, and Analysis for the Greater Everglades (IMMAGE) Habitat Suitability applet showing forecasted amphibian species richness for a sea level rise of $30 \mathrm{~cm}(1 \mathrm{ft})$. 


\section{Sea, Lake, and Overland Surges from Hurricanes Model}

Sea, Lake, and Overland Surges from Hurricanes (SLOSH) is a numerical model developed by the NOAA/NHC to estimate storm surge heights and winds resulting from historical, hypothetical, or predicted hurricanes [Federal Emergency Management Association (FEMA), 2003a, 2003b]. SLOSH uses the hydrodynamic flow equations and requires input of bathymetry, coastal topography, surface characteristics, and tidal levels (Jelesnianski and others, 1992). The coastline is represented as a physical boundary. Subgrid-scale water features (cuts, chokes, sills, and channels), and vertical obstructions (levees, roads, spoil banks, and so forth) are parameterized. The SLOSH model does not include rainfall amounts, river flow, or wind-driven waves; however, these are combined with the model results in the final analysis of at-risk areas.

Using methodologies developed by Longenecker $(2008,2009)$ to incorporate the NHC SLOSH model into the HAZUS-MH Coastal Flood Model (CFM), FEMA Region IV developed a Coastal Flood Loss Atlas (CFLA) to improve risk assessments and mitigation planning for hurricane storm surges on the eastern coast of the United States. In order to establish a baseline "dictionary" to reference hurricane surge losses, the study uses SLOSH to establish maximum potential storm surge depths by hurricane category maximum of maximum's (MOM's). SLOSH divides the coastline into basins and produces a water-surface-elevation grid used to determine depths by subtracting ground elevation. The SLOSH MOM grid is first converted to a raster surface elevation through centroid point interpolation; then USGS 30-meter National Elevation Dataset data are subtracted to determine depth over land. The display resolution of the SLOSH model is 30 meters $(98.4 \mathrm{ft})$. SLOSH model output accuracy varies from \pm 5 to 20 percent, depending on the accuracy of high-water-mark data [National Oceanic and Atmospheric Administration (NOAA), 2013)]. A good overview of the SLOSH model and the factors affecting its accuracy and resolution are provided in Glahn and others (2009).

\section{Multihazard Loss Analysis Program Loss Analyses}

At the present time, the only nationally applicable and standardized methodology for estimating potential losses from floods, earthquakes, and hurricanes is contained within FEMA's multihazard loss analysis program [HAZUS-MH (HAZUS)] loss analysis software (http://www.fema.gov/hazus). HAZUS uses geographic information system (GIS) technology to estimate the physical, economic, and social impacts of disasters. It is used for mitigation and recovery as well as for preparedness and response. HAZUS includes a comprehensive, nationwide database of population and infrastructure at risk. In its fifth release since its introduction in 1992, HAZUS now has an extensive user group, which includes Federal, State, and local government agencies, as well as public utilities, the private sector, and academia.

The HAZUS-MH Flood Information Tool allows rapid analysis of a wide variety of stream discharge data and elevation data to determine flood depth, extent, and frequencies over entire flood plains (http://www.fema.gov/hazus/hazus-flood-informationtool). The flood model also includes a library of more than 900 damage curves for use in estimating damage to various types of buildings and infrastructure. Using these damage estimates, the flood model also estimates shelter requirements and indirect economic losses due to floods. It also allows users to analyze the effects of flood warning, and the benefits of follow-on remapping studies, levees, and elevation of structures. 
In order to use SLOSH model data in HAZUS, a GIS process was developed by Longenecker $(2008,2009)$ to subtract the topography from the SLOSH water surface elevation in order to determine storm surge water depth over land. By executing this process, a raster-based water-depth grid is supplied to HAZUS that represents storm surge inundation for a particular storm track (forecast/response scenario), for a particular storm approach direction or speed (hypothetical scenario), or for entire evacuation areas based on MOM delineation (maximum of maximum possible event for planning purposes).

The accuracy of HAZUS loss estimates is dependent on the quality of input data used. Level 1 analyses are conducted using the best available surge maps and asset data from the U.S. Census Bureau data included in the HAZUS national database and are typically the least accurate. More accurate level 2 loss estimates are produced by including more accurate surge maps and (or) by replacing the default asset inventories with more accurate local inventories of buildings, essential facilities, and other infrastructure. The highest accuracy level 3 analyses include the hazard and inventory improvements in a level 2 study in addition to expert refinement of loss functions and other analysis parameters. HAZUS users typically choose an analysis level based on the costs entailed and the corresponding value of higher accuracy results.

For the IMMAGE project, SLOSH MOM inundation predictions and the accompanying HAZUS surge loss analyses were provided to USGS by FEMA Region IV for Miami-Dade, Broward, and Palm Beach Counties. Asset values from HAZUS's national database were used. The resulting loss analyses were then loaded into the IMMAGE map viewer (figs. 8 and 9). Users are able to access and display several different HAZUS loss categories, including economic losses for several building types and vehicles (daytime and night), displaced population, and accumulated debris. 


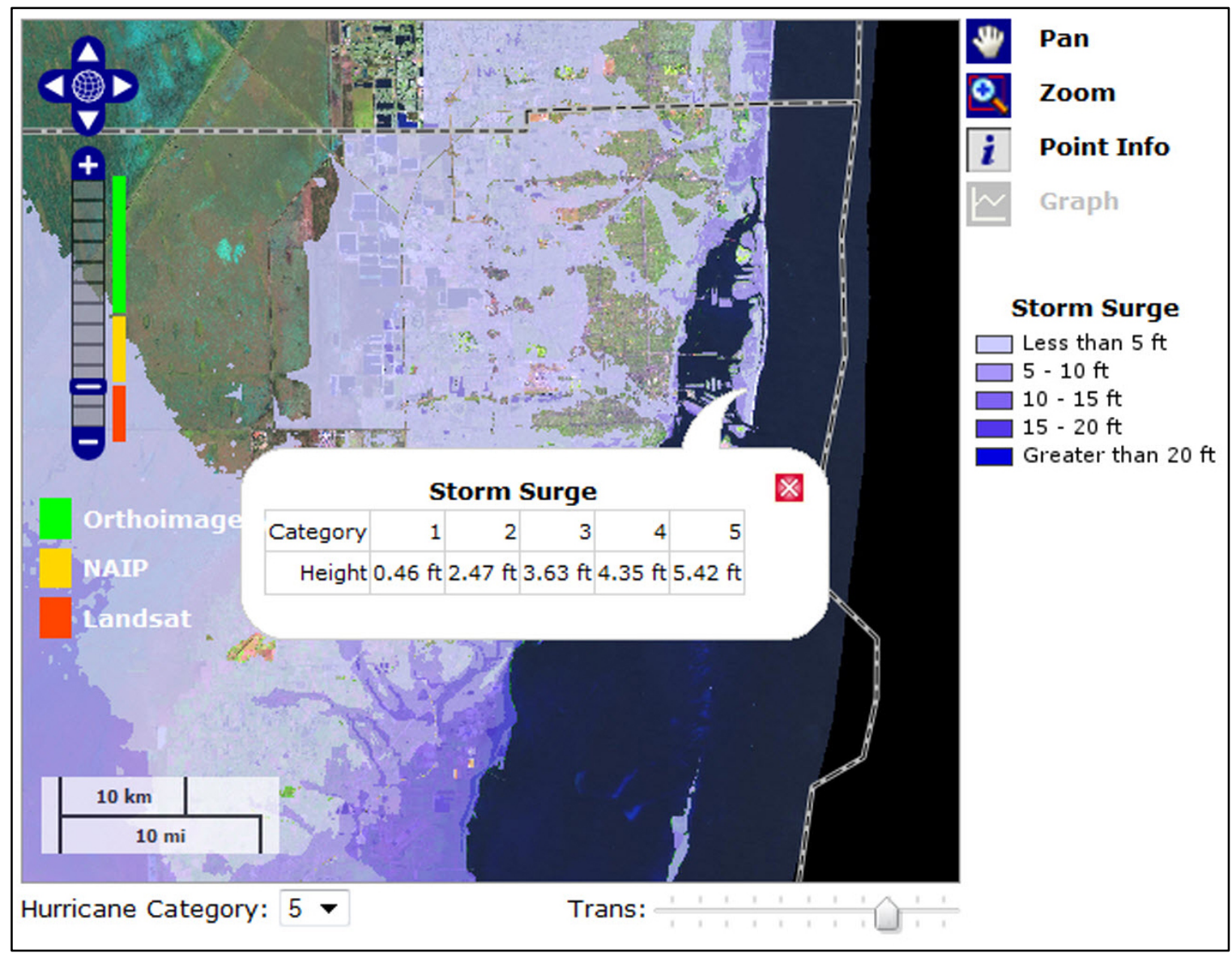

Figure 8. Screenshot of the U.S. Geological Survey's Internet-based Modeling, Mapping, and Analysis for the Greater Everglades (IMMAGE) Sea, Lake, and Overland Surges from Hurricanes (SLOSH) storm surge applet, showing the spatial extent and depth of surge forecasted in the Miami area for a Category 5 hurricane. Modeled surge depths for all storm categories can be accessed for a specific census block using the Point Info tool. 


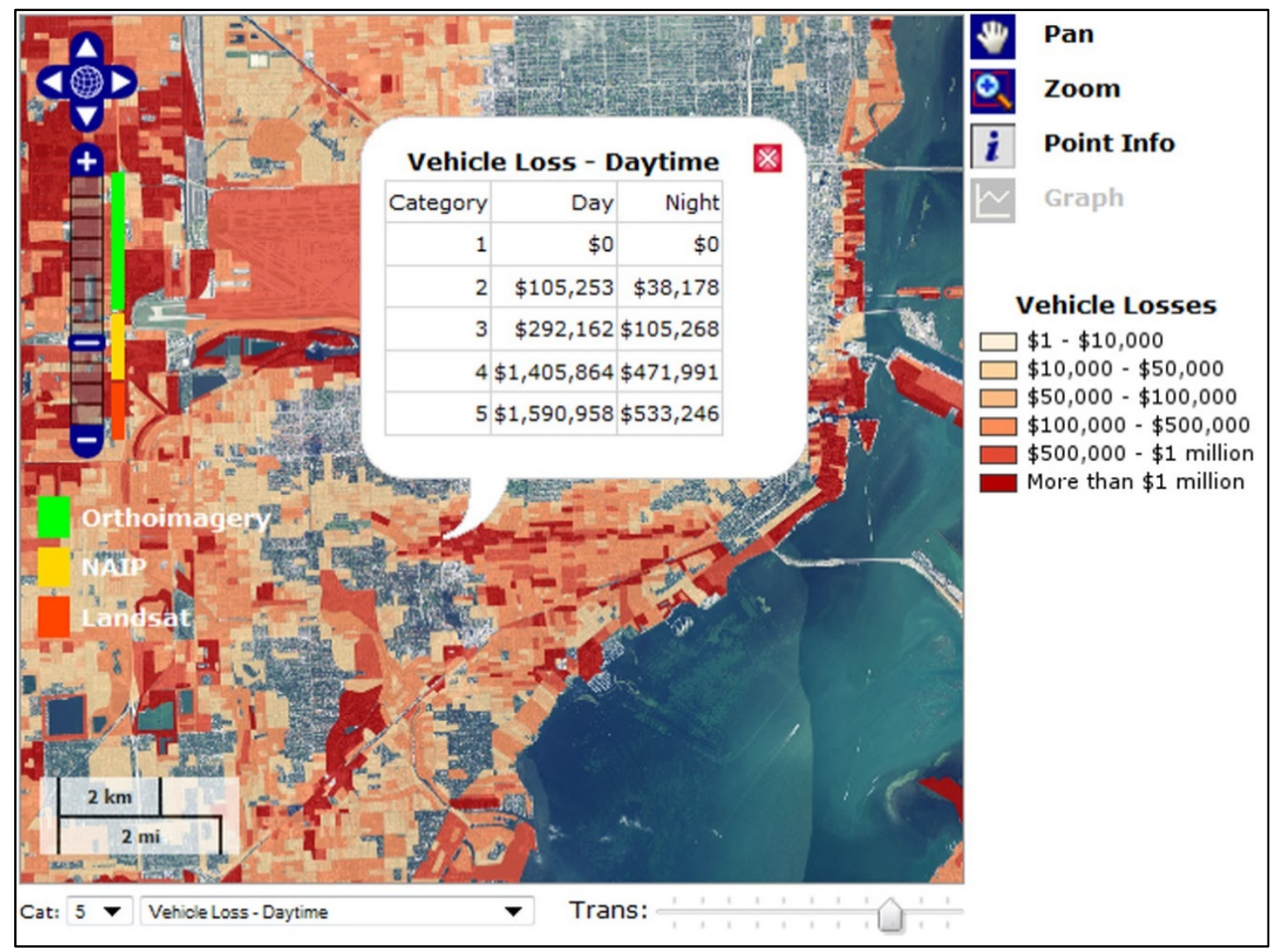

Figure 9. Screenshot of the U.S. Geological Survey's Internet-based Modeling, Mapping, and Analysis for the Greater Everglades (IMMAGE) multihazard loss analysis program [HAZUS-MH (HAZUS)] Surge Loss applet, showing the distribution of forecasted losses from daytime damages to vehicles in the greater Miami area for a Category 5 hurricane. The Point Info tool allows data for all storm categories to be displayed for a selected census block.

\section{Conclusions}

This report documents the development of an advanced Web interface to provide greater awareness and access to modeled data relevant to sea level rise in the Greater Everglades, and its potential impact on local water supplies; the extent of inland flooding, surge, and associated losses from coastal storms; and habitat distribution. The IMMAGE Web site is designed to serve a broad spectrum of users, including scientists, elected officials, government agencies, academia, and the general public. It is hoped that the advanced functionality provided by IMMAGE will serve as a template for the development of similar Web sites to increase public awareness of USGS science and its application to decisionmaking for other issues facing our Nation.

\section{References Cited}

Doyle, R., Bailey, K., and Matheny, 2007, Adaptive response planning to sea level rise planning in Florida and implications for comprehensive and public facilities planning: Department of Urban and Regional Planning, Florida State University, 49 p. 
Federal Emergency Management Agency [FEMA], (2003a), Multi-hazard loss estimation methodology, flood model, HAZUS, technical manual: Washington, D.C.

Federal Emergency Management Agency [FEMA], (2003b), HAZUS-MH User Manual: Washington, D.C.

Glahn, B., Taylor, A., Kurkowski, N., and Shaffer, W.A., 2009, The role of the SLOSH model in National Weather Service storm surge forecasting: National Weather Digest, v. 33, no. 1, p. 3-14.

Jelesnianski, C.P., Chen, J., and Shaffer, W.A., 1992, SLOSH: Sea, Lake, and Overland Surges from Hurricanes: NOAA Technical Report NWS 48, National Oceanic and Atmospheric Administration, U.S. Department of Commerce, $71 \mathrm{p}$.

Labiosa, W.B., Bernknopf, R.L., Hearn, P.P., Hogan, D.M., Strong, D.R., Pearlstine, Leonard, Mathie, A.M., Wein, A.M., Gillen, Kevin, and Wachter, Susan, 2009, The South Florida ecosystem portfolio model-A map-based multicriteria ecological, economic, and community land-use planning tool: U.S. Geological Survey Scientific Investigations Report 2009-5181, 41 p.

Langevin, C.D., Swain, E.D., and Wolfert, M.A., 2005, Simulation of integrated surfacewater/ ground-water flow and salinity for a coastal wetland and adjacent estuary: Journal of Hydrology, v. 314, 212-234.

Lohmann, M., Swain, E., and Decker, J., 2010, BISECT-A Hydrologic Model of South Florida for Evaluating Ecosystem Restoration and Sea-Level Rise: GEER 2010 Greater Everglades Ecosystem Restoration, The Everglades-A Living Laboratory of Change, Planning, Policy and Science Meeting, Naples, FL, p. 190.

Longenecker, H.E., 2008, HAZUS Coastal Flood Module: FEMA Region IV Standard Operating Procedure for Coastal Flood Hazard \& Loss Analysis: Internal FEMA Region IV document, available upon request from the Atlanta, GA office.

Longenecker, H.E., 2009, An Evaluation of the HAZUS Coastal Flood Model: Master's thesis, University of Colorado at Boulder.

Longenecker, H.E., 2011, Development and Applications of the FEMA Region IV Coastal Flood Loss Atlas: Solutions to Coastal Disasters 2011, p. 650-665.

McRae, B.H., Dickson, B.G., Keitt, T.H., and Shah, V.B., 2008, Using circuit theory to model connectivity in ecology and conservation: Ecology, v. 10, p. 2712-2724.

National Oceanic and Atmospheric Administration, National Weather Service, National Hurricane Center (NOAA/NHC), 2013, Sea, Lake, and Overland Surges from Hurricanes (SLOSH), accessed at http://www.nhc.noaa.gov/surge/slosh.php, on June 18, 2013.

Pearlstine, L., DeAngelis, D., Mazotti, F., Barnes, T., Duever, M., and Starnes, J., 2006, Spatial Decision Support Systems for Landscape Ecological Evaluations in Southwest Florida Feasibility Study: University of Florida IFAS Extension CIR 1479, Wildlife Ecology and Conservation Department, University of Florida Cooperative Extension Service, Institute of Food and Agricultural Sciences, 6 p.

Pearlstine, L., Hallac, D., Perry, W., Schmidt, T., Kearns, E., Bahm, K., and Swain, E., 2008, Florida Bay Estuarine Habitat Suitability Assessments of Restoration and Sealevel Rise Interactions: Greater Everglades Ecosystem Restoration Conference, Program and Abstracts, $362 \mathrm{p}$.

Pearlstine, L.G., Pearlstine, E.V. and Aumen, N.G., 2010, A review of the ecological consequences and management implications of climate change for the Everglades: Journal of the North American Benthological Society, v. 29, no. 4, p. 1,510-1,526. 
Renken, R.A., Dixon, J., Koehmstedt, J., Lietz, A.C., and others, 2005, Impact of anthropogenic development on coastal ground-water Hydrology in southeastern Florida, 1900-2000: U.S. Geological Survey Circular 1275, 77 p. (Also available at http://pubs.usgs.gov/circ/2005/circ1275/.)

Ross, M.S., J.F. Meeder, J.P., Sah, P.L. Ruiz, and G.J. Telesnicki, 2000, The southeast saline Everglades revisited - 50 years of coastal vegetation change: Journal of Vegetation Science, v. 11, no. 1, p. 101-112.

Schaffranek, R.W., 2004, Simulation of surface-water integrated flow and transport in two dimensions-SWIFT2D user's manual: U.S. Geological Survey Techniques and Methods, 6 B-1, 115 p. (Also available at http://pubs.usgs.gov/tm/2005/tm6b1/.)

Stabenau, E., Engel, V., Sadle, J., and Pearlstine, L., 2011, Sea-level rise-Observations, impacts and proactive measures in Everglades National Park: Park Science, v. 28, no. 2, p. 26-30.

Swain, E.D., Wolfert, M.A., Bales, J.D., and Goodwin, C.R., 2004, Two-dimensional hydrodynamic simulation of surface-water flow and transport to Florida Bay through the Southern Inland and Coastal Systems (SICS): USGS Water-Resources Investigations Report 03-4287, 56 p., 6 plates. (Also available at http://pubs.usgs.gov/wri/wri034287/.)

Swain, E.D., 2005, A model for simulation of Surface-Water Integrated Flow and Transport in Two dimensions - SWIFT2D user's guide for application to coastal wetlands: U.S. Geological Survey Open-File Report 2005-1033, 88 p., at http://pubs.usgs.gov/of/2005/1033/.

Swain, E.D., and Decker, J.D., 2009, Development, testing, and application of a coupled hydrodynamic surface-water/ground-water model (FTLOADDS) with heat and salinity transport in the Ten-Thousand Islands/Picayune Strand Restoration Project area, Florida: U.S. Geological Survey Scientific Investigations Report 2009-5146, at http://pubs.usgs.gov/sir/2009/5146/.

Swain, E.D., Lohmann, M., and Decker, J.D., 2009, Hydrological simulations of watermanagement scenarios in support of the Comprehensive Everglades Restoration Plan, in Symposium on Role of Hydrology in Water Resources Management, island of Capri, Italy, October 2008, Proceedings: International Association of Hydrological Sciences, v. 327, p. 296-305.

Wang, J.D., Swain, E.D., Wolfert, M.A., Langevin, C.D., James, D.E., and Telis, P.A., 2007, Applications of Flow and Transport in a Linked Overland/Aquifer Density Dependent System (FTLOADDS) to simulate flow, salinity, and surface-water stage in the Southern Everglades, Florida: U.S. Geological Survey Scientific Investigations Report 2007-5010, at http://pubs.usgs.gov/sir/2007/5010/.

Wolfert-Lohmann, M.A., Langevin, C.D., Jones, S.A., Reich, C.S., Wingard, G.L., Kuffner, I.B., and Cunningham, K.J., 2008, U.S. Geological Survey science support strategy for Biscayne National Park and surrounding areas in southeastern Florida: U.S. Geological Survey Open-File Report 2007-1288, 47 p., at http://pubs.usgs.gov/of/2007/1288/. 